\title{
Absence of a radiate morph bearing self- incompatible ray florets from Edinburgh populations of Senecio vulgaris $\mathbf{L}$.
}

\author{
Richard J. Abbott, \\ Judith A. Irwin and \\ David F. Forbes
}

\author{
Department of Biology \& Preclinical Medicine, Sir \\ Harold Mitchell Building, University of St. Andrews, \\ St. Andrews, Fife, KY16 9TH, Scotland, U.K.
}

\begin{abstract}
A survey of the frequency and distribution of radiate plants of Senecio vulgaris possessing capitula bearing selfincompatible ray florets was conducted in Edinburgh and its environs. Offspring were tested of 432 radiate plants sampled from a total of 12 different sites. Two sites were within $100 \mathrm{~m}$ of a site from which a sample of radiate plants had been taken previously by Warren $e t$ al. (1988) and reported to contain a radiate variant bearing self-incompatible ray florets at a frequency of $\mathbf{5 0}$ per cent. All of the radiate plants tested in the present study produced ray florets capable of setting selfed seed. In general, the percentage of seed set on selfing was high in both ray and disc floret fractions (approximately 80 per cent), although in some capitula both floret fractions were characterised by poor seed set. The results failed to confirm the presence in Edinburgh populations of radiate $S$. vulgaris bearing selfincompatible ray florets.
\end{abstract}

\section{INTRODUCTION}

In a recent paper, Warren et al. (1988) reported that within populations of Groundsel, Senecio vulgaris L., that are polymorphic for capitulum type, the radiate morph may occur in two forms in regard to ray floret type. One form produces capitula bearing self-compatible ray florets, while the other produces capitula in which ray florets are selfincompatible. In both forms ray florets are male sterile (lack anthers) while the disc florets are hermaphroditic and fully self-compatible.

From each of three populations: at Edinburgh, Wath-on-Dearne (South Yorkshire) and York, the offspring of 20 randomly sampled radiate plants were tested for possession of self-incompatible ray florets. It was reported that within these small samples the radiate variant with self-incompatible ray florets occurred at frequencies of 50, 25 and 65 per cent respectively. Self-incompatibility was inferred from: (i) failure of self-pollen to penetrate the surface of one stigmatic lobe in each of five virgin ray florets of a single capitulum tested per plant, while cross pollen successfully penetrated the surface of the other stigmatic lobe in each floret; (ii) failure of ray florets to set seed when selfed while successful seed set resulted from crosspollination.
Subsequently, it was shown that when unemasculated capitula from different plants were rubbed together, radiate plants with self-incompatible ray florets only produced crossed seed in these florets whereas in plants with self-compatible ray florets, crossing was reduced by approximately 50 per cent in the ray florets. Moreover, Warren (1988) found that self-incompatible ray florets exhibited 100 per cent natural outcrossing in artificial polymorphic stands in the field, whereas self-compatible ray florets showed approximately 29 per cent outcrossing.

The detection of radiate plants with self-incompatible ray florets at relatively high frequencies in three different polymorphic populations of Senecio vulgaris was surprising in view of the fact that such plants had not been identified in previous studies concerned with the genetics and breeding system of the radiate morph (Trow, 1912; Hull, 1972; Marshall \& Abbott, $1982 ; 1984 a, b)$. In any study in which radiate plants are raised from seed under insect-free conditions, individuals with self-incompatible ray florets may be indicated through the production of capitula which, on fruiting, bear an outer ring of aborted ovules.

To determine the frequency and distribution of radiate plants possessing self-incompatible ray florets in populations located in Edinburgh, a study 
was conducted which involved screening the offspring of 432 radiate plants sampled from populations polymorphic for capitulum type over 12 different sites in the Edinburgh area. Two of the sites from which plants were sampled were within $100 \mathrm{~m}$ of the Edinburgh site (Grid reference NT261735) sampled previously by Warren et al. (1988).

\section{MATERIALS AND METHODS}

Radiate plants at the flowering and fruiting stage were collected from 12 different sites in Edinburgh and its environs (table 1) in May 1987 and May 1989. From each plant, one progeny was raised singly in pots, from seed to the flowering stage in a glasshouse at St. Andrews between June and August following collection. After a plant had begun to flower, a capitulum was chosen prior to anthesis and placed in a bag made of lens tissue. This procedure excluded pollinators from visiting the capitulum and ensured self-pollination. Approximately two weeks after bagging, at a stage when fruit formation had been completed, each capitulum was carefully removed from its bag and a record was taken of whether the ray florets had set seed. For plants raised from seed collected in May 1989, an additional record was taken of the number of seed produced by ray and disc florets of the same capitulum. From these values a measure of floret fertiility was obtained for each floret fraction in terms of the percentage of florets that set seed. In the rare instances in which a capitulum produced a complete ring of aborted ovules in the ray florets, a second capitulum from

Table 1 Location of Edinburgh sites and the number of parent radiate plants $(n)$ sampled per site

\begin{tabular}{llr}
\hline Location & $\begin{array}{l}\text { National Grid } \\
\text { Reference }\end{array}$ & $n$ \\
\hline *Newhailes (1) & NT 337725 & 51 \\
*Newhailes (2) & NT 337726 & 37 \\
*Newhailes (3) & NT 338725 & 32 \\
*Niddrie & NT 313717 & 32 \\
*Old Craighall & NT 335708 & 35 \\
*Salamander St. & NT 276763 & 48 \\
†Cowgate (1) & NT 258735 & 16 \\
†Cowgate (2) & NT 256734 & 3 \\
†Cowgate (3) & NT 262735 & 4 \\
†Drummond St. & NT 261734 & 71 \\
†Seafield Rd. & NT 297748 & 58 \\
$\dagger$ North Leith & NT 267765 & 45 \\
\hline
\end{tabular}

* Sample May 1987.

$\dagger$ Sampled May 1989. the same plant was bagged and examined to check for consistency.

\section{RESULTS AND DISCUSSION}

Of the progeny of 432 radiate plants tested, only three produced a capitulum in which all ray florets failed to set seed. In each case the capitulum tested was considered as odd in that the fertility of the disc florets was also low, and more importantly, a subsequent test of another capitulum on each individual showed that their ray florets were fully capable of setting selfed seed.

It was established from the progenies of plants sampled in May 1989 that mean fertility (i.e., percentage of florets to set seed) of ray and disc florets was $79.5 \pm 3.4$ per cent and $84.6 \pm 2.4$ per cent respectively. Excluding the zero values of the three individuals which failed to set seed in ray florets of the first capitulum tested, the fertility values for ray florets ranged from $8 \cdot 3-100$ per cent, and for disc florets from 21.3-100 per cent; however, the bulk of capitula had fertility values exceeding 80 per cent in both floret fractions. Over the 197 plants surveyed the fertility of ray and disc florets (transformed into angles) was positively correlated ( $r=$ $\left.0 \cdot 66^{* * *}\right)$.

The results of the survey failed to confirm the presence of radiate plants bearing capitula with self-incompatible ray florets in Edinburgh populations of $S$. vulgaris as reported previously by Warren et al. (1988). Warren et al. (1988) reported that such plants occurred at a frequency of 50 per cent among the offspring of a sample of 20 radiate individuals collected from a site very close to the Cowgate (3) and Drummond St. sites (table 1) sampled in the present study and not far from two other Cowgate sites which were also sampled. In the present study, progenies of plants sampled from these and other sites in Edinburgh produced capitula which, in general, exhibited high mean seed set on selfing in both the ray and disc floret fractions. In no instance did a progeny produce capitula with self-incompatible ray florets.

Self-incompatibility in the Compositae is of the sporophytic type, SSI (Richards, 1986). Most work on SSI has been conducted on species of Cruciferae, particularly Brassica spp. In Brassica, it has been shown that the SI reaction occurs only at the stigma surface and is absent from buds until 1 to 2 days before anthesis (Hodgkin, Lyon and Dickinson, 1988). The reaction is known to break down at elevated temperatures, relative humidity and $\mathrm{CO}_{2}$ concentration (Hodgkin et al. 1988), but 
there are no reports that self-incompability is reduced by bagging, i.e., enclosing flowers in bags. The type of bag used in the present study was made of lens tissue and has been employed frequently by us in selfing and crossing lines of the related self-incompatible species Senecio squalidus L. On no occasion has it been found that bagging results in a reduction of the SI reaction in Senecio squalidus. We are confident, therefore, that failure to find radiate plants of $S$. vulgaris which produce self-incompatible ray florets does not stem from the method of investigation, i.e., automatic selfed seed set following bagging.

Our results do not, of course, disprove the existence of a radiate form of $S$. vulgaris bearing self-incompatible ray florets. However, they do demonstrate that such plants are either absent from, or extremely rare, in Edinburgh populations of $S$. vulgaris that are polymorphic for capitulum type. Furthermore, they make clear that detailed surveys are required at other localities where it has been indicated that the morph may occur at a high relative frequency based on the preliminary study of Warren et al. (1988).

Acknowledgements This work was supported by a research grant from the N.E.R.C. (GR3/6203) to R.J.A.

\section{REFERENCES}

HODGKIN, T., LYON, G. D. AND DICKINSON, H. G. 1988. Recognition in flowering plants: A comparison of the Brassica self-incompatibility system and plant pathogen interactions. New Phytol., 110, 557-569.

HULL, P. 1974. Self-fertilisation and the distribution of the radiate form of Senecio vulgaris L., in Central Scotland. Watsonia, 10, 69-75.

MARShAlL, D. F. AND ABBotT, R. J. 1982. Polymorphism for outcrossing frequency at the ray floret locus in Senecio vulgaris L. I. Evidence. Heredity, 48, 227-235.

MARSHALL, D. F. AND ABBOTT, R. J. 1984a. Polymorphism for outcrossing frequency at the ray floret locus in Senecio vulgaris L. II. Confirmation. Heredity, 52, 331-336.

MARShALL, D. F. AND ABBotT, R. J. 1984b. Polymorphism for outcrossing frequency at the ray floret locus in Senecio vulgaris L. III. Causes. Heredity, 53, 145-149.

RICHARDS, A. J. 1986. Plant Breeding Systems. Allen \& Unwin, London.

TROW, A. H. 1912. On the inheritance of certain characters in the common groundsel, Senecio vulgaris L., and its segregates. J. Genet., 2, 239-276.

WARREN, J. M. 1988. Outcrossing frequencies within and between capitulum morphs in groundsel Senecio vulgaris L. Heredity, 61, 161-166.

WARREN, J. M., CRAWFORD, T. J. AND OXFORD, G. S. 1988. Pollen inhibition systems in Senecio vulgaris L. Heredity, 60, 33-38. 